Branding of Government Services

\title{
Branding of Government Services: Benefits and Challenges
}

\author{
Aravind Reghunathan \\ Bournemouth University, \\ Poole, United Kingdom. \\ E-mail: areghunathan@bournemouth.ac.uk
}

\begin{abstract}
Till recently, brand management was perceived as a function exclusive to commercial organizations. However, the experiences of several nations have shown that branding can be an effective tool for managing government services also. This paper discusses the benefits of the current practices of branding in governance. A coherent branding strategy assists the departments in the formulation and delivery of services by having clarity of purpose and consistency in communication. The citizen benefits in various ways from a streamlined execution of the strategy. The paper also identifies the challenges for brand management to grow in the governance sphere.
\end{abstract}

Key Words: Services branding, government branding, public sector branding, e-governance, employer brand 


\section{Introduction}

Extant research has established that a brand is an asset for any business (D. A. Aaker \& Keller, 1990; He \& Calder, 2020). At the same time, branding has found applications in fields other than business, including but not limited to non-profit organizations, events, personalities, ideas, and information. Recent experiences of many nations across the globe have shown that brand management can be successfully adopted in politics and governance also (Downer, 2015; Eshuis \& Klijn, 2012). Branding practices are increasingly prevalent in the formulation and execution of government services and schemes, and the running of government departments. The decision to organize all government departments in the United Kingdom under the gov.uk address can be considered as an illustration of this trend (Marland et al., 2017).

Communication of information and recruitment for the administrative functions are other areas that have also changed on account of branding in government (Reichenberg, 2002). By way of social marketing, the use of marketing concepts to bring about behavioural changes had already found acceptance (Sahadev et al., 2020). Such practices aim to show a unity of purpose, communication cohesiveness, and message simplicity (Eshuis \& Klijn, 2012; Marland et al., 2017).

In this paper, a preliminary attempt is made to understand the current branding strategies in this field, their benefits, and the major challenges ahead. One of the motives of this perspectives paper is to point out the scope of branding for the governance of an emerging economy. The rest of the paper is organized as follows: We begin with a review of the literature to explore the benefits of the brand management practices in the government sphere. Following this, we discuss the challenges ahead for branding in governance. We conclude by briefly highlighting the limitations of the paper and the scope for further research.

\section{Literature Review}

\section{Current Practices and Benefits}

The increasingly popular practice of governments using marketing techniques to enhance the access and quality of the service provided is recognized in the extant literature (Crompton \& Lamb, 1986; Marland et al., 2017). Moving away from selling orientation, the governments and departments now identify the needs of the citizens first and create appropriate services 
based on that understanding (Lamb \& Crompton, 1986). Sahadev et al. (2020) illustrate the social marketing case of tackling excessive alcohol consumption in the United States by segmenting the target groups before planning interventions. Recent developments in public administration have established that several of such strategies that go into effective corporate branding can be a huge boon for governance.

Branding helps to generate trust in the services provided (Karens et al., 2016). As a majority of the government departments directly interact with the public, the ability to generate a sense of trust can bring wider participation of the public in availing the services and schemes offered. Arya et al. (2019) have argued that trust helps to bring an emotional attachment to the brand. When a government scheme applies a well-designed brand strategy, the public easily understands its goals and identifies themselves with it (Contentgroup, 2016). This would also eliminate any confusion that the public might have as a good brand essentially communicates as a distinct personality (J. L. Aaker, 1997; Grohmann, 2009). The use of celebrities to promote social services can be viewed as another application of brand management practices in the public sector. In several communities, celebrities are regarded as a trustworthy source of information, and marketers take advantage of this impression in promoting products and services (Gauns et al., 2018).

A brand facilitates effective communication with the public and makes it easier for an entity to spread its messages (Abroms \& Maibach, 2008). For instance, when the department of public works has completed an infrastructure project, the public is immediately able to know whom to credit. A related advantage of branding a government programme is that the public will be more aware it has the backing of a trusted source. According to Karens et al. (2016), a brand indicates not only where a product or service come from, but also what makes it identifiable. This calls for a closer alignment between the policy message and its originator. Inviting entries from the public for the design of mascots is a usual practice in Olympics host nations. Thus, getting the ideas from the public at all stages of the scheme would help to generate a participative feeling with the target group (Scammell, 2003).

The objectives of branding in government services are similar to any commercial branding activity. The New Zealand government's draft guidelines creating an all-of-government brand policy report in 2007 lists out the following main objectives (All-of-Government Brand Policy and Guidelines, 2007): 
Unity: A branded initiative can show a unity of purpose across the state services, providing cohesion for individual departments of the government.

Visibility of the government activity: Public recognition and recall are improved by linking government-funded services, initiatives, and programmes through consistent imagery.

Credibility: The clear identification of services to a government brand aims to develop credibility and trust. Accountability is another significant factor leading to an impression of trust in the minds of the public.

Transparency: The branding practice should clearly show the spending from the exchequer and this helps to indicate the returns.

Digital media, governance, and branding: The move towards e-governance has enabled governments to improve the efficiency of public administration (Bhuiyan, 2011). Such initiatives provide easier and faster access to information, thereby improving the delivery of public services (Lee-Geiller \& Lee, 2019). The way citizens consume information has changed beyond recognition and communicating public policy matters through one-way broadcast spectrums may not be effective. Consequently, social media avenues have also been tapped for governance initiatives (Bertot et al., 2012; Charalabidis \& Loukis, 2012). Marland et al. (2017) have observed that government departments use branding strategies to manage the proliferation of information in digital media. Apart from the simplicity and consistency offered, such strategies align employee activities and communication touchpoints with a common purpose (Eshuis \& Klijn, 2012; Scammell, 2003).

Government as an employer brand: Industry experts opine that the private sector is far ahead of the government in projecting itself as an employer of choice (e.g.: Tuutti, 2012) and cite several reasons for critical skills shortages in the public sector including lower compensation packages, old-fashioned human resource management practices, and declining image of the public sector. However, branding government or its departments to move way from such an image is still not properly done. Past research has established that having a strong brand image helps in attracting and retaining talent (Kucherov \& Zavyalova, 2012). For example, despite the constraints associated with the public sector, NASA attracts top talent from around the world because the agency is one of the most recognisable employer brands.

Barrow and Mosley (2011) define an employer brand to be a package of economic, functional, and psychological benefits identified with the employing entity. In agreement, 
Kucherov and Zavyalova (2012) consider a well-defined employer brand to have the following attributes: economic (e.g.: salary, fair system of rewards and bonuses), psychological (e.g.: organizational culture and team cohesion), functional (e.g.: the content of work, and opportunities for training and development), and organisational (e.g.: leadership in its respective segment and management style). Through clear communication, the public sector needs to convey what sets them apart from competitors in these attributes and align them with the candidates' objectives. A robust branding strategy for any government initiative must communicate how it positively creates meaning and affect the lives of people (Antonopoulos, 2012).

\section{Challenges Ahead}

Ensuring that branding practices do not equate to trends of centralization in governance is of paramount importance. Marland et al. (2017) have observed that the authority of central agents increases when several initiatives are organized under one master brand. Such a trend can be particularly concerning for a federal nation such as India. Besides, an 'all-consuming brand' may lead to the loss of identity and policy autonomy for departments and ministries. Related to this, there is a risk of marketing strategies in public sector converging with digital media and abused as propaganda (Baines \& O’Shaughnessy, 2014).

In many of the emerging economies, getting public participation on a single platform and convincing the public about spending money on an intangible aspect such as brands can be difficult. Several communication consultants have expressed apprehension on how a rather formal identity of a brand works with campaigns that are intended to engage people (L'Etang et al., 2015). Often, government agencies commit the mistake of hastily creating a brand when any new initiative is announced, without having any coherent brand strategy. For a citizen-oriented government initiative, communicating how it is meaningful for the daily lives of the target audience is crucial. The focus should always be on the people; brand strategy must show an understanding of who they are, how they tick, and how to communicate with them (Antonopoulos, 2012).

Most people fail to associate the services they experience with the government initiative that has given them the same (Antonopoulos, 2012). This indicates a clear lack of brand awareness and hence, the clamour for a singular brand image. If executed well, the public places great trust in services that have been understood to come from the government (Sibbick et al., 2007). This trust would also help in increasing the scope of extending the 
brand in the future. For example, extending the Swatch Bharat brand in India to other lesserknown cleanliness initiatives would be possible only if there is sufficient brand awareness of the parent scheme among the target group. Similar to the practices of any customer-oriented brand, government initiatives need to have transparency and accountability in their operations. In several emerging economies, departments are instructed to develop a more citizen-oriented approach with effective communications at the heart of this push.

About projecting itself as an employer brand, the challenge before governments are to incorporate the following three key components in their messages (Tuutti, 2012):

Relevance: The brand has to resonate with the jobseekers. They have to feel the brand's relevance to their objectives through its communication. Reichenberg (2002) recognizes the declining image of the public sector among young people and emphasizes the importance of staying relevant.

Differentiation: What sets a government apart from others should be highlighted to jobseekers. For instance, an India government job is often perceived to offer job security. The government as a brand has to understand that multiple employers are vying for the candidates they are looking to attract (Reichenberg, 2002).

Sustainability: The central themes through which the brand is projected currently must be sustainable propositions for the foreseeable future also. Otherwise, retaining talent will remain to be a challenge, despite investing resources in the recruitment, training, and development of employees.

Moreover, providers of the government service have to ensure that communication has to be followed with efficient delivery. As conveying the benefits of the idea to the target group is a crucial part of branding (Padgett \& Allen, 1997), citizens would have certain expectations about the service even before availing it. Hence, the ground situation must be in line with the brand communication.

\section{Conclusion and Limitations}

Branding government services and departments are still in their nascent stage, especially in emerging nations. At the same time, the benefits of these practices are well-established for all the stakeholders concerned. They achieve a unity of purpose, help in increasing visibility, credibility, and trust; and create an atmosphere of transparency for the government and its 
agencies. The public also gets benefitted from increased awareness and participation in decision-making. However, marketing is not the panacea for all the service delivery and accountability issues confronting government departments (Crompton \& Lamb, 1986), and the major challenges listed in the current article confirm the view.

A major limitation of this review is that one of the most extensively researched fields in this area - nation or place branding- has not been considered. We intended to explore the scope of branding the government and its services with an emphasis on benefits to citizens, more than focusing on a singular image for the outside world. Subsequently, further research is warranted on how government services branding can assist to achieve various objectives such as promoting tourism and ease of doing business image. 
Branding of Government Services

Note

An earlier version of this article was presented at the $11^{\text {th }}$ NASMEI Conference, organized by the Great Lakes Institute of Management in December 2017.

\section{References}

Aaker, D. A., \& Keller, K. L. (1990). Consumer Evaluations of Brand Extensions. Journal of Marketing, 54(1), 27. https://doi.org/10.2307/1252171

Aaker, J. L. (1997). Dimensions of Brand Personality. Journal of Marketing Research, 34(3), 347. https://doi.org/10.2307/3151897

Abroms, L. C., \& Maibach, E. W. (2008). The Effectiveness of Mass Communication to Change Public Behavior. Annual Review of Public Health, 29(1), 219-234. https://doi.org/10.1146/annurev.publhealth.29.020907.090824

All-of-Government Brand Policy and Guidelines (2007), Newzealand.govt.nz. State Services Commission, Crown Copyright.

Antonopoulos, J. (2012). Management: Branding for government agencies. Government News. https://search.informit.org/doi/abs/10.3316/informit.073030856565896

Arya, V., Verma, H., Sethi, D., \& Agarwal, R. (2019). Brand Authenticity and Brand Attachment: How Online Communities Built on Social Networking Vehicles Moderate the Consumers' Brand Attachment. IIM Kozhikode Society \& Management Review, 8(2), 87-103. https://doi.org/10.1177/2277975219825508

Baines, P. R., \& O’Shaughnessy, N. J. (2014). Political Marketing and Propaganda: Uses, Abuses, Misuses. Journal of Political Marketing, 13(1-2), 1-18. https://doi.org/10.1080/15377857.2014.866018

Barrow, S., \& Mosley, R. (2011). The Employer Brand: Bringing the Best of Brand Management to People at Work. John Wiley \& Sons.

Bertot, J. C., Jaeger, P. T., \& Hansen, D. (2012). The impact of polices on government social media usage: Issues, challenges, and recommendations. Government Information Quarterly, 29(1), 30-40. https://doi.org/10.1016/j.giq.2011.04.004

Bhuiyan, S. H. (2011). Modernizing Bangladesh public administration through e-governance: Benefits and challenges. Government Information Quarterly, 28(1), 54-65. https://doi.org/10.1016/j.giq.2010.04.006 
Branding of Government Services

Charalabidis, Y., \& Loukis, E. (2012). Participative Public Policy Making Through Multiple Social Media Platforms Utilization. Int. J. Electron. Gov. Res. https://doi.org/10.4018/jegr.2012070105

Crompton, J. L., \& Lamb, C. W. (1986). Marketing government and social services (Vol. 10). Wiley New York.

Downer, L. (2015). Political Branding Strategies: Campaigning and Governing in Australian Politics. Springer.

Eshuis, J., \& Klijn, E. H. (2012). Branding in Governance and Public Management. Routledge.

Gauns, K. K., Pillai, S. K. B., Kamat, K., Chen, R. F., \& Chang, L.-C. (2018). Impact of Celebrity Endorsement on Consumer Buying Behaviour in the State of Goa. IIM Kozhikode Society \& Management Review, 7(1), 45-58. https://doi.org/10.1177/2277975217733897

Grohmann, B. (2009). Gender Dimensions of Brand Personality. Journal of Marketing Research, 46(1), 105-119.

He, J., \& Calder, B. J. (2020). The experimental evaluation of brand strength and brand value. Journal of Business Research, 115, 194-202. https://doi.org/10.1016/j.jbusres.2020.04.035

How can government strengthen their brand? (2016). Contentgroup. https://contentgroup.com.au/2016/11/can-government-strengthen-brand/

Karens, R., Eshuis, J., Klijn, E.-H., \& Voets, J. (2016). The Impact of Public Branding: An Experimental Study on the Effects of Branding Policy on Citizen Trust. Public Administration Review, 76(3), 486-494. https://doi.org/10.1111/puar.12501

Kucherov, D., \& Zavyalova, E. (2012). HRD practices and talent management in the companies with the employer brand. European Journal of Training and Development, 36(1), 86-104. https://doi.org/10.1108/03090591211192647

Lamb, C. W., \& Crompton, J. L. (1986). Contrasting marketing and selling orientations in Government organizations. Journal of Professional Services Marketing, 2(1-2), 157167.

Lee-Geiller, S., \& Lee, T. (2019). Using government websites to enhance democratic Egovernance: A conceptual model for evaluation. Government Information Quarterly, 36, 208-225. https://doi.org/10.1016/j.giq.2019.01.003

L'Etang, J., McKie, D., Snow, N., \& Xifra, J. (2015). The Routledge Handbook of Critical Public Relations. Routledge. 
Branding of Government Services

Marland, A., Lewis, J. P., \& Flanagan, T. (2017). Governance in the Age of Digital Media and Branding. Governance, 30(1), 125-141. https://doi.org/10.1111/gove.12194

Padgett, D., \& Allen, D. (1997). Communicating Experiences: A Narrative Approach to Creating Service Brand Image. Journal of Advertising, 26(4,), 49-62.

Reichenberg, N. (2002). Branding the Government As An Employer of Choice. International Public Management Association, http://unpan1.un.org/intradoc/groups/public/ documents/UN/UNPAN021819.pdf

Sahadev, S., Malhotra, N., \& Mukherjee, A. (2020). Segmenting Excessive Alcohol Consumers: Implications for Social Marketing. IIM Kozhikode Society \& Management Review, 9(2), 213-225. https://doi.org/10.1177/2277975220913366

Scammell, M. (2003). Citizen Consumers. Media and the Restyling of Politics: Consumerism, Celebrity and Cynicism. Sage Publishing: Thousand Oaks, CA, USA.

Sibbick, J. B., Previte, J. A., \& Russell-Bennett, R. (2007, September 24). Is government branding 'just wall paper' or does it enhance product acceptance: Conceptualising brand influence in social marketing. International Non-Profit and Social Marketing Conference. International Non-profit and Social Marketing Conference. https://eprints.qut.edu.au/18035/

Tuutti, B. C. (2012). Why branding matters-Even in government -. FCW. Retrieved April 24, 2021, from https://fcw.com/articles/2012/09/28/agencies-employer-brand.aspx 